\title{
ERRATUM
}

\section{AJI VOLUME 112 ISSUE 2 COVER AND FRONT MATTER—ERRATUM}

doi: 10.1017/ajil.2018.46, Published by Cambridge University Press, 30 May 2018.

CONTEMPORARY PRACTICE OF THE UNITED STATES RELATING TO INTERNATIONAL LAW-ERRATUM

doi: 10.1017/ajil.2018.38, Published by Cambridge University Press, 30 May 2018.

Due to a typesetting error, we regret that the section editor for Contemporary Practice of the United States was incorrect on the original published version of the table of contents ${ }^{1}$ and the Contemporary Practice of the United States title page. ${ }^{2}$ Both pages have been updated since original publication with the correct section editor, Jean Galbraith.

${ }^{1}$ AJI Volume 112 Issue 2 Cover and Front Matter, 112 AJIL F1-F8 (2018), doi:10.1017/ajil.2018.46.

${ }^{2}$ Executive Branch Imposes Limited Russia-Related Sanctions After Statutory Deadlines, 112 AJIL 296-303 (2018), doi:10.1017/ajil.2018.38. 